\title{
nature
}

9 August 2001 Volume 412 Issue no 6847

\section{A sound approach to GM debate}

If genetic modification is to yield benefits in socially acceptable ways, governments need to ensure that there is broad but well-focused consultation. A New Zealand commission provides an excellent example.

$\mathrm{F}$ ew areas of science and technology touch as directly on the lives of citizens as genetic research. So it is not surprising that scientists working at its frontiers find their enthusiasm for the technological and social possibilities challenged by a tide of public opinion (real or apparent) and ambivalent political responses. Whatever researchers may believe about the benefits, the future of genetically modified (GM) crops and foods depends on the prosperity of companies wishing to invest in their development and on the willingness of farmers, retailers and consumers to buy them. Those market forces in turn depend critically on regulation and public attitudes.

Thus it has been encouraging to witness the constructive and sensitive approach adopted by the New Zealand government in establishing a Royal Commission on Genetic Modification as applied to research, medicine and agriculture. Its scope and processes have been unique, as justifiably claimed by New Zealand's prime minister, Helen Clark, on releasing its valuably comprehensive report last week (see page 573).

According to the report, "genetic modification" was to be addressed in all its ramifications, not overtly for the global interest, but for New Zealand's better management of its own immediate challenges. Yet the report did not consider the issues in South Pacific isolation. The inquiry cast its net for witnesses worldwide, and merits international readership (see http://www. gmcommission.govt.nz). In the end, a campaign to make New Zealand a genetic-engineeringfree zone has, with transparent justice, been dealt a heavy blow from which it will be difficult for it to recover, although New Zealand's Green Party vows to "fight on".

\section{A mbition rew arded}

The commission's remit was an ambitiously broad one for four people to tackle in little over a year. They were charged with covering the whole gamut of scientific, economic, environmental, ethical, indigenous, intellectual-property, legislative and regulatory angles of safety and risks of genetic modification.

New Zealand is a compact society, and its economy is heavily dependent on the competitive export of agricultural produce. In an economy that has been slipping steadily in the world rankings, there has been a strong push for genetic research and application to become the saviour that delivers enhanced productivity.

On the other side has been a politically vociferous Green movement, with seven members of parliament who theoretically hold the balance of power over the Labour-Alliance coalition. The Greens successfully pressed for the establishment of the Royal Commission. This is a form of quasi-judicial inquiry in countries that inherited British law which ensures its independence of government and institutions and confers powers not available to other forms of inquiry, in particular the cross-examination of witnesses.

Taking account of the sensitivities of Maori, the indigenous community comprising about $12 \%$ of the population of 3.9 million and with special rights under the nineteenth-century Treaty of Waitangi, was an overriding condition. That need resonates with many other nations in resolving questions of the ownership of native biota.
The commission chairman and former chief justice, Sir Thomas Eichelbaum, guided the broad involvement by general public and experts alike, beginning with 'scoping' meetings to define the issues more clearly. Eichelbaum is proud of having incorporated social and indigenous values into the management of genetic science: "Few minds may have been changed in the process but everyone emerged better informed and more willing to listen to each other."

\section{Wide cons ultation}

The commissioners consulted widely — and always openly — through 15 public meetings and three forums across the country, including special emphasis on Maori, with whom they held 11 "hui" (community gatherings). Evidence was taken from 107 "interested persons", who first had to qualify under the Commissions of Inquiry Act. Some of them presented their cases with legal backing, and witnesses were cross-examined by commissioners, their legal counsel and opposing parties. But this was not conducted in the adversarial manner that scientists called as expert witnesses in court rightly detest.

For a small country, the commission attracted a huge number of submissions $(10,861)$. These were overwhelmingly against genetic modification ( $92 \%$, and $65 \%$ strongly so). But an extensive public survey found a different balance of opinion. Prompted to nominate important issues, only $2 \%$ mentioned GM concerns. The report is replete with detailed analyses of submissions that ultimately reinforced the commissioners' decision to reject the Greens' key policy.

Jean Fleming, a reproductive biologist at the University of Otago, found that her fellow commissioners were influenced in the end by the greater weight of scientific evidence over assertions about risk. She perceived that there were few entrenched 'anti-scientists' among participants, as all sides called for more research on areas of doubt. However, a lack of trust of scientists was evident, with many blaming the influence of the profit motive forced on researchers in New Zealand since a massive restructuring of public science ten years ago. Fleming was saddened by the fact that the submissions of several scientists, on whose evidence the Greens were basing their case of unacceptable risk, fell apart under cross-examination.

New Zealand's consultation stands in markedly favourable contrast to its neighbour's approach. In Australia, communications to and from the public are less clear, with five government departments involved and none being advised by consultative processes remotely similar to the New Zealand inquiry.

Having established a model of community consultation and scientific rigour that other nations may consider emulating, the New Zealand government cannot rest on its laurels. Some of the commission's recommendations require further public resources. It is all too easy to request more funds for research, but the commission is surely right to highlight the need for publicly funded exploration of the environmental impact of GM crops as well as research into organic and other sustainable agricultural systems. But the report's recommendations are much more wide-ranging and, in places, contentious. To consolidate the commission's good work, the New Zealand government will need to legislate with determination. 